\title{
АНТИВІТАЛЬНІ ПЕРЕЖИВАННЯ ЯК ЧИННИК СУЇЦИДАЛЬНИХ ІДЕАЦІЙ ТА СУЇЦИДАЛЬНОГО РИЗИКУ
}

\section{Шевчук О. С.}

\section{ВСТУП}

Передбачення суїцидальної поведінки викликає ряд труднощів, які пов'язують 3 наявністю багатьох індивідуальних чинників суїцидального ризику, непостійністю, мінливістю предиспозуючих перемінних і їx поєднань ${ }^{1}$. Розвиток суїцидальної динаміки може мати як певні патокінетичні стереотипи, зокрема при певних психічних захворюваннях та патологіях, так і аспекти поведінкових реакцій. Таким чином, виділення комплексу критеріїв для прогнозу суїцидальної активності має враховувати предиктори суїцидальної поведінки та інші суїцидогенні фактори.

Суїцидальна поведінка виступає процесом, у якому суїцидальна активність прогресує від початкових стадій малоусвідомлених внутрішніх форм до практичної реалізації суїцидальних дій².

Пошук предикторів суїцидальної поведінки не дозволив виділити надійних критеріїв передбачення суїциду. Ступінь серйозності суїцидального наміру може формуватися за впливу таких груп суїцидогенних факторів, як: індивідуально-особистісні особливості, ситуаційно-особистісні характеристики обставин та статусноособистісні суїцидогенні чинники ${ }^{3}$.

Прогноз суїцидальної спроби та іiі повтору має враховувати антисуїцидальні фактори, оскільки вони прямо впливають на ризик здійснення самогубства та можуть надавати змістовну інформацію для проведення терапевтичних та превентивних заходів. У пресуїцидальному періоді практично завжди присутній психічний стан амбівалентності аутоагресивних (суїцидальних) мотивів, який

1 Шевчук О.С. Особливості підходу до психодіагностики антивітальних переживань. Проблеми особистості в сучасній науці: результати та перспективи дослідження, 17 березня 2017 р. : Матеріали XIX Міжнародної конференції молодих науковців / за ред. І.В. Данилюка, С.Ю. Пащенко. Київ : Логос, 2017. С. 336-339.

2 Зотов П.Б., Уманский С.М. Клинические формы и динамика суицидального поведения. Суицицология. 2011. № 1. С. 3-7.

${ }^{3}$ Дзюб Г.К., Кузнецов В.М., Нестерчук Н.В. Ургентна психіатрія (клініка, психодіагностика, терапія невідкладних станів). Київ, 2010. С. 77-91. 
характеризується одночасним існуванням

аутоагресивних (суїцидальних) та антисуїцидальних мотивів ${ }^{4}$.

Це дослідження розглядає феномен суїцидальної поведінки через розкриття психологічної сутності внутрішньої форми пресуїцидального етапу, а саме шляхом дослідження антивітальних переживань як чинника формування суӥцидальних ідеацій та суїцидального ризику.

\section{1. Теоретичні засади дослідження особливостей суӥцидальної поведінки}

Суїцидальна поведінка - це варіант поведінки особистості, що характеризується свідомим прагненням покінчити 3 собою (мета смерть, мотив - вирішення або зміна психотравмуючої ситуації шляхом добровільного відходу з життя), тобто будь-які внутрішні і зовнішні форми психічних актів, що спрямовуються уявленнями про позбавлення себе життя ${ }^{5}$. Суїцидальна поведінка має певні форми, способи здійснення, стадії розвитку, предиктори, фактори ризику і так далі.

Суїцидальну поведінку прийнято підрозділяти на внутрішні i зовнішні форми активності, що проявляють себе на різних етапах суїцидальної поведінки.

До внутрішніх форм поведінки належать: антивітальні переживання (роздуми про відсутність цінності життя без чітких уявлень про свою смерть), пасивні суїцидальні думки (фантазії на тему своєї смерті, але без активного позбавлення себе життя), суїцидальні задуми (розробка плану суїциду), суїцидальні наміри (рішення про виконання суїцидального плану).

До зовнішніх форм належать: самогубство (навмисне, усвідомлене, швидке позбавлення себе життя), суїцидальна спроба (навмисне самоушкодження, що не закінчилося смертю, або самоотруєння, яке націлене на реалізацію бажаних суб'єктом змін за рахунок фізичних наслідків), перервана суїцидальна спроба (акт, здійснений 3 метою навмисного самоушкодження або самовбивства, але перерваний до реального самоушкодження зовнішніми обставинами).

У рамках суїцидальної поведінки суїцидальна активність прогресує від початкових стадій малоусвідомлених внутрішніх форм до практичної реалізації суїцидальних дій.

${ }^{4}$ Билле-Браге У., Чуприков А.П., Пилягина Г.Я., Войцех В.Ф., Крыжановская Л.А., Жабокрицкий С.В., Сонник Г.Т. Глоссарий суицидологических терминов. Методическое пособие. URL: http://www.psychiatry.ru/lib/56/book/110 (дата звернення: 20.04.2020).

5 Клінічна психологія: словник-довідник / авт.-уклад. С.В. Діденко. Київ : Академвидав. Серія "Nota bene", 2012. С. 206-207. 
Виділяють 3 етапи динаміки суїцидальної активності: пресуїцидальний етап, етап реалізації суїцидальних дій та постсуїцидальний етап. Своєю чергою внутрішні форми суїцидальної активності - це антивітальні переживання, суїцидальні думки, суїцидальні задуми та суїцидальні наміри. Зовнішні форми - це суїцидальні спроби та завершений суїцид 6 . Важливим $є$ дослідження не лише зовнішніх форм, а і внутрішніх, адже саме на пресуїцидальному етапі йде значна внутрішня боротьба, відбувається пошук сенсу існування в умовах, які склалися, і так далі. Отже, своєчасна діагностика та кваліфікована допомога, подана в цей період, могли б бути найбільш важливими елементами профілактики самогубств.

У зв'язку з різною мотивацією суїцидальну поведінку розділили на «істинну» та «демонстративно-шантажну». Істинними суїцидальними діями вважають усвідомлені умисні дії, метою і мотивом яких $\epsilon$ добровільне позбавлення себе життя.

Демонстративно-шантажні аутоагресивні дії - несмертельне умисне самопошкодження 3 низькою суїцидальною вірогідністю, спрямоване на отримання яких-небудь переваг від демонстрації намірів позбавити себе життя. Найчастішими формами $\epsilon$ порізи шкіри, навмисні самопідпали, подряпини, удари, проколювання частин тіла, виривання волосся, вживання токсичних речовин тощо.

Розрізняють такі види самогубств ${ }^{7}$ :

1) неусвідомлюване самогубство;

2) самогубство як ризикована гра і ризикована легковажність;

3) психопатологічне й агресивно-невропатичне самогубство:

- маніакальне самогубство осіб, охоплених галюцинаціями або мареннями;

- самогубство меланхоліків у стані глибокого смутку, скорботи, гіпертрофованих докорів совісті, суму, журби;

- самогубство охоплених нав'язливими ідеями;

- автоматичне чи імпульсивне самогубство;

4) самогубство психічно нормальної людини 3 такими видами суїцидальної поведінки:

- демонстративно-шантажна форма суїцидальної поведінки;

- внутрішні і зовнішні форми суїцидальної поведінки: внутрішні: суїцидальні думки, уявлення, емоційні переживання, задуми, наміри; зовнішні: суїцидальні спроби і завершені суїциди;

6 Зотов П.Б., Уманский С.М. Клинические формы и динамика суицидального поведения. Суицицдология. 2011. № 1. С. 3-7.

7 Кузнецов В.Е. Комплексные исследования в суицидологии. Москва, 1986. C. 84-93. 
- егоїстичний суїцид, що виникає через руйнування соціальних зв'язків особистості з суспільством;

- альтруїстичний суїцид, який виникає у формі самопожертви задля захисту інтересів групи (фанатики тощо);

- аномічний суїцид, який виникає внаслідок виснаження;

- суїцид, спровокований засобами масової інформації;

- суїцид, спричинений депресією.

Мотиви суїцидальної поведінки - це особистісні спонукання, що викликають бажання добровільного відходу із життя. Дослідники виділяють п’ять основних груп мотивів. До них належать такі ${ }^{8}$ :

- протест - реакція негативної дії на об’єкти, що викликали психотравматичну ситуацію (помста); сенс суїцидів «протесту» полягає в непримиренності, у бажанні покарати кривдників, завдати їм шкоди хоч би фактом власної смерті;

- заклик, суть якого полягає в тому, щоб активізувати реакції оточення, викликати своєю смертю їх співчуття, співпереживання;

- при суїцидах «уникнення» покарання або страждання сенс полягає в усуненні себе від нестерпої загрози особистісному або біологічному існуванню, позбавленні себе від тяжкого психічного чи соматичного стану;

- самопокарання - спокутування «власної провини» шляхом здійснення суїцидальних дій;

- відмова від життя - мета і мотив суїцидальної поведінки при цьому співпадають, сенс самознищення можна характеризувати як «повну капітуляцію».

Деякими вченими виділяється таке явище, як амбівалентність аутоагресивних (суїцидальних) мотивів ${ }^{9}$. Це психічний стан, що характеризується одночасним існуванням аутоагресивних (суїцидальних) i антисуїцидальних мотивів. Практично завжди присутній у пресуїцидальному періоді. Може використовуватися як основа для проведення корекційних та профілактичних заходів шляхом активізації антисуїцидальних факторів особистості.

Антивітальні переживання представляють собою найбільш ранній етап суїцидальної динаміки. Вони характеризуються поступовим посиленням прихованих і малоусвідомлених авітальних тенденцій, які ослаблюють прагнення підтримувати життя.

8 Клінічна психологія: словник-довідник / авт.-уклад. С.В. Діденко. Київ : Академвидав. Серія "Nota bene", 2012. С. 206-207.

9 Билле-Браге У., Чуприков А.П., Пилягина Г.Я., Войцех В.Ф., Крыжановская Л.А., Жабокрицкий С.В., Сонник Г.Т. Глоссарий суицидологических терминов. Методическое пособие. URL: http://www.psychiatry.ru/lib/56/book/110 (дата звернення: 20.04.2020). 
Зазвичай формування антивітальних переживань починається 3 втрати бажання жити. В подальшому з'являються мотиви бажаності близької смерті від природних причин. У цьому разі людина частіше розглядає смерть як можливий вихід із ситуації, що склалася, але ще не замислюється про можливості добровільного відходу 3 життя. Антивітальні переживання не виступають на перший план і зазвичай проявляються у вигляді висловлювань: «втомився так жити ...», «якби б хто знав, як мені набридло мучитися...», «часом хочеться заснути і не прокинутися...» та інші. По суті, це скарги депресивного характеру, що $\epsilon$ умовою для обов'язкового більш глибокого обстеження та цілеспрямованого опитування 3 метою виявлення суїцидальної налаштованості. Крім вербальних ознак, антивітальна налаштованість може проявлятися і іншими симптомами - небажанням співпраці 3 оточуючими, ігноруванням допомоги та невиконанням певних рекомендації чи порад, що могли б покращити стан та інші. Важливо відзначити, що, попри зовні негативну реакцію, більшість осіб навпаки потребують i шукають психологічної підтримки. Наявні сумніви i переживання у важкій життєвій ситуації потребують пошуку рішень.

На етапі антивітальних переживань суїцидальний ризик мінімальний, тому що характеризується високою активністю психологічних захистів i значимістю факторів антисуїцидального бар'єру ${ }^{10}$. Проте продовження дії стресових чинників у певний момент може привести людину до усвідомлення особистої відповідальності за свою долю, що в цьому разі може спровокувати розгляд можливості до самостійного позбавлення себе життя. 3 цього моменту суїцидальна динаміка вступає в етап суїцидальних думок та може розвитися впритул до зовнішніх форм суїцидальної активності у вигляді завершеного суїциду.

На цей момент виділено певні особливості, характеристики, що описують загальні риси, властиві всім формам проявів суїцидальної поведінки та методам реалізації суїцидальних дій, а саме: 1) основною ціллю $є$ пошук рішення в умовах фрустрації певних психологічних потреб; 2) загальний фон переважання емоцій безнадії та безпомічності; 3) стимулом суїцидальної поведінки може виступати невимовний психічний біль; 4) внутрішнє ставлення амбівалентності; 5) загальний стан психіки характеризується звуженням когнітивної сфери; 6) загальне прагнення діяльності це втеча (агресія); 7) комунікативні акти свідчать про намір скоїти самогубство;

${ }^{10}$ Кузнецов В.Е. Комплексные исследования в суицидологии. Москва, 1986. C. 84-93. 
8) загальна закономірність: відповідність суїцидальної поведінки загальному стилю поведінки суїцидента.

Суїцидальний ризик - це ступінь ймовірності виникнення суїцидальних мотивів, формування суїцидальної поведінки і здійснення суїцидальних дій. Ступінь вираженості суїцидального ризику (ймовірність здійснення суїцидальних дій) можна визначити шляхом зіставлення суїцидогенних і антисуїцидальних факторів особистості, а також ступенем впливу особистісно-ситуаційних (характер і значимість суїцидогенного конфлікту) і середовищних (соціально-демографічних) факторів. Розрізняють такі варіанти суїцидального ризику ${ }^{11}$ :

- гострий: висока ймовірність здійснення суїцидальних дій (пресуїцидальний період може бути «миттєвим»), слід розглядати як невідкладний стан;

- хронічний: тривале існування терапевтично резистентних суїцидальних переживань, не усунених після скоєння суїцидальної спроби.

Таким чином, ймовірність самогубства можна розраховувати на основі клінічної оцінки хворобливого стану пацієнта i/aбо, за даними тестування, в якому, як передбачається, підвищується ймовірність скоєння суїциду (через депресію, інші психічні захворювання, виявлений психопатологічний синдром, деякі особливості поведінки, що вказують на тенденцію до самопошкоджуючої поведінки).

Фактори ризику (суїцидогенні фактори) - це будь-які причини, умови або впливи, що викликають як етіопатогенетичний компонент формування суїцидальної поведінки. До них можна віднести: демографічні, психопатологічні, психологічні, біологічні, психічні травми та інші фактори. Антисуїцидальними факторами своєю чергою $\epsilon$, наприклад, соціальна підтримка, адаптивні механізми долаючої поведінки, моральне неприйняття самогубства тощо.

Таким чином, було прийняте рішення про застосування концепції суїцидальної поведінки (за А.Г. Амбрумовою) 3 метою перевірки гіпотези цього дослідження. Ця концепція описує уявлення про те, що кожен випадок самогубства описується співвідношенням середовищних, особистісних та психопатологічних (за їх наявності) факторів $^{12}$. Основні аспекти концепції полягають у тому, що: 1) до основних діагностичних категорій суїцидентів належать психічно хворі

11 Кузнецов В.Е. Комплексные исследования в суицидологии. Москва, 1986. C. 84-93.

12 Билле-Браге У., Чуприков А.П., Пилягина Г.Я., Войцех В.Ф., Крыжановская Л.А., Жабокрицкий С.В., Сонник Г.Т. Глоссарий суицидологических терминов. Методическое пособие. URL: http://www.psychiatry.ru/lib/56/book/110 (дата звернення: 20.04.2020). 
3 ендогенними психопатологічними розладами, хворі 3 межовими розладами та практично здорові люди; 2) у всіх суїцидентів виявляються об'єктивні та суб'єктивні ознаки соціально-психологічної дезадаптації, яка може бути парціальною або тотальною (залежно від ступеню i характеру порушення основних напрямів адаптаційної діяльності: пізнавальної, перетворюючої, комунікативної та ціннісноорієнтаційної); 3) у всіх випадках вирішальним моментом формування маніфестуючих суїцидальних проявів $є$ суїцидогенний конфлікт; 4) прийняття суїцидального рішення (поза залежністю від причин, умов, форм дезадаптації) відбувається лише після етапу особистісної переробки суїцидогенного конфлікту; не існує безпосередньої залежності суїцидальної поведінки від характеру i тяжкості хворобливих переживань; навіть за наявності у суїцидента психотичного стану «псевдореальний» конфлікт заломлюється через базальні установки особистості, що зумовлює вибір характеру поведінки, що слідує за ним.

Для вивчення такого комплексного феномену, як формування антивітальних переживань, які можуть трансформуватися в суїцидальні ідеації та впливати на суїцидальний ризик, варто поєднувати індивідуально-психологічний, соціально-психологічний та загальнопсихологічний контексти вивчення особистості.

Відповідно до цього 3 метою розв'язання питань у цьому дослідженні було визнано доцільним застосування системного підходу, з урахуванням таких особливостей психічної реальності та активності людини, як ставлення до майбутнього у формі ядра мотивації, смисложиттєвих орієнтацій, загальної адаптованості особистості, форм та стратегій поведінки щодо подолання конфліктів та життєвих негараздів загалом, взаємодії з соціальним оточенням та розуміння i приймання кінцевої форми існування.

3 огляду на вищезазначені особливості дослідження було використано такі методики: 1) Опитувальник суїцидального ризику (ОСР) О.Г. Шмельова; 2) П'ятифакторний особистісний опитувальник; 3) Методика «Ціннісні орієнтації» Рокіча; 4) Опитувальник «Способи долаючої поведінки» Лазаруса; 5) Методика діагностики міжособистісних відносин Лірі.

\section{2. Змістовна інтерпретація результатів факторного аналізу}

Отримані результати дослідження було проаналізовано за допомогою факторного та регресійного аналізу. Більш якісним виявився саме факторний аналіз, адже він дозволяє узагальнити отримані дані шляхом зменшення розмірності вихідних даних шляхом пояснення їх варіації меншим числом факторів та обчисленням 
факторів як нових інтегративних змінних. Відповідно, було структуровано вихідні дані, проведено опосередковану оцінку змінних у разі неможливості їх прямого вимірювання та створено основу для генерації нових ідей 3 оцінкою відповідності емпіричних даних використаній теорії на етапі іiі підтвердження та побудові нових конструктів. Відповідно, за допомогою факторного аналізу було отримано 11 факторів, які було змістовно проінтерпретовано.

Інтерпретація результатів, отриманих внаслідок ортогонального обертання як одного з етапів факторного аналізу, дозволила виявити наступні фактори (в цьому разі «егоїстичність» вживається як синонім «направленості на себе», тобто всередину, а «соціальність» - як «направленість на соціальне оточення», тобто назовні) реагування особистості відповідно до прояву антивітальних переживань в умовах конфлікту:

1. Соціальна егоїстичність

У цей фактор входять такі змінні, як: цінність особистого життя, цінності спілкування, цінності прийняття інших людей, позитивна переоцінка, альтруїстичні цінності, егоїстичний тип міжособистісних стосунків, самоконтроль, гіпертимність, авторитарний тип міжособистісних стосунків, демонстративність, долаюча поведінка у вигляді копінгу планування вирішення проблеми.

Цей фактор описує позитивну адаптованість в умовах конфлікту, а саме помірну соціальну орієнтованість із високим рівнем збереження власних меж. Таким чином, можна свідчити про те, що ведучими цінностями для людини в такому разі є цінність особистого життя, на противагу професійній самореалізації тощо. Важливими для такої людини, попри все, залишається прийняття людей, проте воно досягається шляхом авторитарного типу міжособистісних стосунків, 3 достатньо високим рівнем демонстративності та задоволенням егоїстичних потреб. Така людина буде достатньо розсудливою та поміркованою у вирішенні проблем, що виникають, саме тому це дозволяє ій за рахунок позитивної переоцінки долати негативні переживання шляхом переосмислення їх як стимулу для задоволення власного особистісного росту. Гнучкість розуму дозволяє бути достатньо пластичним і в той же час може викликати певне утруднення для людини у тому, щоб перебувати весь час на одному місці за однією справою. Переважний фон настрою загалом достатньо доброзичливий та позитивний, проте зрідка може супроводжуватися незначною дратівливістю.

\section{2. Сочіальна конформність}

У цей фактор входять такі змінні, як: цінність справи, інтегральний показник суїцидального ризику, конформістські цінності, приймання 
відповідальності,

міжособистісних стосунків, підкоряючийся тип міжособистісних стосунків, тривожність, конфронтаційний копінг.

Цей фактор описує адаптивний тип поведінки в умовах конфлікту, а саме високу соціальну орієнтованість із порушенням власних меж. У разі високого навантаження людина буде уникати вирішення справи 3 метою зменшення психологічного тиску на себе, інколи вона може робити це i на противагу власним переконанням i бажанням. Здійснювати вона це може через пожертвування собою як в позитивному ключі (альтруїстичний тип поведінки), так i в негативному ключі (підкоряючийся тип поведінки) для своєї особистості в рамках формування міжособистісних стосунків. Достатньо сильно усвідомлює межі власної відповідальності, тому може докоряти собі у разі порушення обіцянок, даних іншим людям, так і собі (зрідка). Таким чином, з метою вирішення конфлікту людина може скоювати суїцид заради збереження своєї особистості або заради суспільного вищого блага. В рамках співіснування 3 травмуючими ситуаціями такий тип поведінки може супроводжуватися відходом у свою особистість, у рамках заперечення об'єктивно наявної проблеми, відповідно, така людина може фантазувати, мати певні невиправдані очікування щодо вирішення ситуації або певної суперечності.

3. Мінлива егоїстичність

У цей фактор входять такі змінні, як: циклотимність характеру, збудливість характеру, тривожність характеру, відсутність конкретних цілей, цінності самоствердження, відсутність самоконтролю, абстракті цінності, інтегральний показник суїцидального ризику, індивідуалістичні цінності.

Цей фактор описує адаптивний тип поведінки в умовах конфлікту, а саме ігнорування соціальної орієнтованості із розмитими адаптивними власними межами. Такі люди не схильні до того, аби протиставляти себе іншим, вони вважають себе краще. Будь-які прояви настрою можуть мати характер спалаху і також само швидко затухати. В періоди гарного настрою вони налаштовані оптимістично та 3 легкістю долають певні труднощі на своєму шляху. Щодо соціуму, то вони здатні легко вступати 3 ним у контакт, адже гнучко підлаштовують власні межі до ситуації, яка утворилася. Таку перевагу їм дає їх висока лабільність, але водночас в умовах конфлікту або небезпечної загрозливої ситуації, вони можуть мати неочікувану навіть для себе реакцію, відповідно, таку ж і для соціуму. Якщо в структуру особистості увійшло негативне ставлення до себе, то вони будуть самостверджувати себе саме у цьому ключі, і навпаки. Зазвичай такий тип поведінки настільки ситуативний, що неспроможний бути 
розрахованим на довготривалу перспективу. Такі люди точно знають лише те, що у майбутньому радше будуть підлаштовуватися, аніж будуть будувати щось власноруч. Відсутність соціальної орієнтації може завдавати значної шкоди, особливо в кризові періоди, коли важливим є саме соціальне оточення індивіда. Також вони будуть мати певні труднощі в умовах мікросоціального конфлікту, адже не завжди можуть мати настільки стійку та водночас гнучку структуру особистості щоб протистояти проблемам. Саме тому, оскільки вони $є$ певною мірою відділені від соціуму, вони можуть переживати соціальну відстороненість і, відповідно, тривожність.

\section{4. Розважлива егоїстичність}

У цей фактор входять такі змінні, як: цінності самоствердження, індивідуалістичні цінності, абстрактні цінності, конкретні цінності, професійна самореалізація, планування вирішення проблеми, низька агресивність у міжособистісних стосунках, пошук соціальної підтримки.

Цей фактор описує адаптивний тип поведінки в умовах конфлікту, а саме помірну соціальну орієнтованість із чітким регулюванням поведінки власними цінностями та уявленнями. Якщо їх характер достатньо мінливий та адаптивний, то така людина буде просуватися по життю, проте певний стрижневий каркас цінностей у іiі житті буде все одно присутнім, адже це все, чим керується така особистість. Загрозу складають умови, за яких іде значна переоцінка цінностей, адже це може змінити не лише поведінку, а і когнітивну й емоційновольову сферу такої людини. Проте, оскільки існує орієнтація на соціальне оточення та пошук соціальної підтримки через взаємодію у мирному ключі, то така особистість може бути цілком пристосованою до життя та важких життєвих умов, що склалися. Інколи щодо емоційного реагування така людина може видатися холодною та відстороненою, проте це все також залежить від особливостей тих цілей та орієнтирів, що складають іiі каркас реагування. Своєю чергою наявність певного роду домінування раціонального над емоціональним дозволяє достатньо чітко діяти в певних кризових ситуаціях $\mathrm{i}$, відповідно, стримувати, або ж навпаки фасилітувати свої емоції.

5. Соціальна залежність

У цей фактор входять такі змінні, як: емотивність характеру, альтруїстичний тип міжособистісних стосунків, приймання відповідальності, залежний тип міжособистісних стосунків, пошук соціальної підтримки, інтегральний показник суїцидального ризику, втеча-уникнення.

Цей фактор описує адаптивний тип поведінки в умовах конфлікту, а саме помірну соціальну орієнтованість із вразливими внутрішніми 
межами. Така особистість достатньо вразлива, чутлива до соціального впливу, тому може як легко образитися, так і легко переживати життєві негаразди, перебуваючи в позитивно налаштованому щодо неї мікросоціальному оточенні. Проте характер зміни поведінки чи емоційного реагування йде за механізмом зараження, адже існує певний рівень усвідомлення щодо скоєння певних дій, хоч і на перший погляд видається, що емоції на першому плані. Така людина здатна приймати відповідальність, але вона буде занадто сильно емоційно залучена та буде справді вболівати за те, що вона робить. Саме тому $є$ ризик глибоко переживання невпевненості, така особистість може реагувати на невдачі у реакціях уникнення і втечі від реальності. Тому можливе повне ігнорування проблеми, що може свідчити про дезадаптивність прояву, хоча насправді така поведінка може врятувати людину від сильного душевного потрясіння, що своєю чергою може врятувати їй життя, адже є ризик скоєння суїциду, зокрема в умовах конфлікту з мікросоціальним середовищем. Тому, якщо в кризових ситуаціях надати такій особистості соціальну підтримку, вона може легше впоратися із проблемою та, відповідно, швидше вийти iз загрозливого для себе стану.

\section{6. Соціальна ригідність}

У цей фактор входять такі змінні, як: застрягаюча акцентуація характеру, педантична акцентуація характеру, дистимність характеру, недовірливий тип міжособистісних стосунків, агресивний тип міжособистісних стосунків, відсутність приймання відповідальності, альтруїстичний тип міжособистісних стосунків.

Цей фактор описує адаптивний тип поведінки в умовах конфлікту, а саме помірну соціальну орієнтованість із вразливими внутрішніми межами. Такій людині важко перемикатися між зовнішньою та внутрішньою діяльністю. Вона може бути надзвичайно старанною, проте може навпаки бути надзвичайно дріб'язковою, як і під час виконання певних справ, так і в міжособистісних стосунках. Може уникати відповідальності через свою принциповість, обов'язковість чи відсутність орієнтації на цінності групи. Може бути достатньо агресивною та властолюбною. Оскільки інколи виступає самонадіяною в умовах конфлікту, може зазнати поразки і тяжко ії переживати. Така загальна риса, як дистимність характеру, визначає постійне його пониження i, відповідно, несміливе ставлення щодо прийняття важливих рішень у своєму житті. Проте перевагою може виступати нестандартний тип мислення і переживання відчуття справедливості або несправедливості щодо себе, або свого найближчого оточення, що і дозволяє встановлювати близькі соціальні контакти, які своєю чергою можуть набувати характеру залежності. Тому порушення стосунків 3 
найближчим соціальним оточенням може викликати достатньо серйозні переживання та створити ризик як для самої людини, так і ï оточення. Проте ті люди, що не підривають довіру, зазнають позитивного ставлення до себе, адже така особистість починає проявляти щодо них свою альтруїстичну і доброзичливу сторону.

\section{7. Захисна егоӥстичність}

У цей фактор входять такі змінні, як: дистанціювання, агресивний тип міжособистісних стосунків, етичні цінності, конкретні цінності, пошук соціальної підтримки, втеча-уникнення, цінності прийняття інших людей, дружелюбний тип міжособистісних стосунків.

Цей фактор описує адаптивний тип поведінки в умовах конфлікту, а саме помірну соціальну орієнтованість із адаптивними внутрішніми межами. Характерним для цієї особистості є переживання конфлікту за рахунок суб'єктивного зниження їі значущості та відмежування емоційного залучення, з використанням раціоналізації, переключення уваги, жартів тощо. Така людина може видаватися агресивною, проте це може лише вказувати на те, що вона послуговується своїми цінностями та уявленнями. Викликавши довіру у такої особистості, можна знайти у ній вірного друга і товариша, адже вона є достатньо вірною щодо своїх поглядів. В умовах мікросоціального конфлікту може зазнати певних негативних переживань, але за умов підтримки може 3 легкістю їх подолати. Може бути достатньо обережною у справах, але при цьому вправно виконує поставлені перед нею конкретні цілі і завдання, як під час роботи, так і в повсякденному житті. Загалом втеча і відмежування від певних проблем виступають тут радше як засіб відпочинку для розуму та емоцій, аніж прагнення відмежувати себе від вирішення певних питань. Саме тому такий тип поведінки є достатньо адаптивним щодо сьогоденних умов існування, проте може відрізнятися певними загостреннями щодо важливих i цінних для людини переживань.

\section{8. Соціальна налаштованість}

У цей фактор входять такі змінні, як: залежний тип, тривожність, відсутність дистимності, конформістські цінності, дружелюбний тип міжособистісних стосунків, альтруїстичні цінності, демонстративність, відсутність недовірливості.

Цей фактор описує адаптивний тип поведінки в умовах конфлікту, а саме високу соціальну орієнтованість із помірним відмежуванням себе. Такий тип поведінки в конфліктних ситуаціях характерний для особистості, що може бути достатньо безпомічною щодо соціального оточення, а тому не може проявляти спротив чи навпаки, вважає, що інші праві щодо того, яким чином потрібно діяти, відчувати чи міркувати. Попри це, вона може бути навпаки довірливою та достатньо 
позитивно налаштованою щодо людей, адже прагне отримати соціальну підтримку, тому інколи може жертвувати собою, проте навіть не усвідомлювати цього до кінця. $€$ достатньо простою та приємною у спілкуванні людиною, адже не проявляє себе, а більшою мірою дає можливість розкритися іншому. Інколи, коли така людина прагне «бути хорошою», коли вона не може виконати певні умови цінності, може достатньо важко переживати такий конфлікт i, відповідно, страждати без соціальної підтримки, особливо від значимих для неї людей. Саме тому така людина може слідувати певним правилам та принципам чи інтегрувати групові принципи в свою поведінку з метою свого позитивного бачення, інколи навіть не лише в очах інших, а і в своїх очах. Може бути ентузіастом своєї справи i активно досягати цілей, поставлених перед нею групою або важливими і значимими людьми. Може видаватися демонстративною, проте таким чином буде лише намагатися проявити свої найкращі сторони 3 метою того, щоб їі помітили і могли по достоїнству оцінити. Може змінювати свою лінію поведінки в умовах соціальної депривації і трансформувати iii залежно від своїх уявлень, якщо такі ще залишилися від багаторазових спроб мімікрувати з певним соціальним середовищем.

\section{9. Егоїстична відстороненість}

У цей фактор входять такі змінні, як: конфронтаційний копінг, втеча-уникнення, професійна самореалізація, авторитарний тип, циклотимність характеру, педантичність, конформістські цінності, дистимність характеру.

Цей фактор описує адаптивний тип поведінки в умовах конфлікту, а саме мінімальну соціальну орієнтованість із чітким відстоюванням внутрішніх меж. Характеристикою такого типу поведінки буде цілеспрямована діяльність щодо здійснення певних конкретних цілей або певних дій, що задовільнять певні потреби чи прагнення людини. Саме тому активним може виступати організація свого життя за типом кар'єрного росту, 3 ігноруванням особистого життя. Можлива імпульсивність поведінки, що може свідчити про розрядку певного напруження. Інколи саме 3 цією метою людина відмежовує себе від оточення та відходить у свій внутрішній світ переживань та думок. Інколи може видаватися холодною, розсудливою, розважливою та авторитарною навіть щодо свого близького оточення. Можлива певна бідність емоційного реагування та понижений емоційний фон через надмірну інтелектуалізацію того, що відбувається у житті такої людини. Така людина може протиставляти себе іншим, але при цьому не буде вважати себе кращою, адже все одно потребуватиме соціальної підтримки і заохочення. Можливі певні емоційні хвилі реагування, проте вони швидко проходять та свідчать про життєву важливість того, 
що так могло схвилювати цю людину у будь-якій із сфер їі життя. Саме тому під час сильних душевних переживань, що ззовні можуть ніяк практично себе не проявляти, така особистість може потребувати турботи про себе та може ставати конформною щодо того, аби отримати необхідну їй в цей момент соціальну підтримку.

\section{0. Егоїстична поміркованість}

У цей фактор входять такі змінні, як: екзальтованість, відсутність пошуку соціальної підтримки, професійна самореалізація, відсутність абстрактних цінностей, конкретні цінності, етичні цінності, підкоряючийся тип міжособистісних стосунків, відсутність планування вирішення проблеми.

Цей фактор описує адаптивний тип поведінки в умовах конфлікту, а саме мінімальну соціальну орієнтованість із чітким відстоюванням внутрішніх меж. Люди такого типу можуть бути сприйняті як сильні вольові особистості, адже практично не шукають соціальної підтримки і все одно залишаються достатньо пластичними через достатньо високу швидкість протікання психічних процесів. Такі люди зазвичай сприймаються також, як «живі», адже достатньо інтенсивно реагують на будь-які навіть незначні події свого життя, при цьому вони можуть як впадати в депресію, так і навпаки бути в достатньо мрійливому та щасливому настрої. Такі люди достатньо конкретно і чітко виконують поставлені перед ними завдання як і ззовні, так і свої власні проекти та задумки. Інколи через певну вразливість щодо значимих сторін свого життя вони можуть впадати в стосунки, в яких будуть підкорятися, проте лише тоді і тільки тоді, коли це не суперечить їх власним установкам та вподобанням. Хоча це може виступати для них значимим джерелом отримання підтримки від мікросоціального оточення. Оскільки вони можуть бути достатньо пластичними, то в конфліктних ситуаціях вони роблять першими кроки, щодо вирішення певних незручностей, особливо якщо це заважає їх самореалізації та розкриттю. Це може відбуватися інтуїтивно, адже планування своєї діяльності не є для них характерним, вони краще себе почувають, коли орієнтуються «на місцевості», аніж планують щось заздалегідь, оскільки через порушення планів може бути змарновано дорогоцінний час. Часто можуть виконувати щось, чого не хочуть, але що слід, виконавши в останній момент, адже є людьми обов'язку та слідують певним етичним нормам.

\section{1. Впевнена егоїстичність}

У цей фактор входять такі змінні, як: гіпертимність, авторитарний тип, відсутність недовірливості, абстрактні цінності, відсутність інтегрального показнику суїцидального ризику, егоїстичний, залежний, конформістські цінності. 
Цей фактор описує адаптивний тип поведінки в умовах конфлікту, а саме мінімальну соціальну орієнтованість із чітким відстоюванням внутрішніх меж. Ззовні таку поведінку можна описати як свободолюбну, впевнену, активну, соціально незалежну, безтурботну. Людина перебуває зазвичай у доброму гуморі та здатна 3 легкістю вирішувати певні проблеми чи переступати через перепони на своєму шляху. Тому інколи сприймається як достатньо авторитарна, хоча $\mathrm{i}$ може бути такою у своїх переконаннях, прагне контролювати своє життя, а дуже часто і оточуючих. Може бути дещо ригідною щодо зміни своїх уподобань, але дуже рідко страждає через це. Така людина любить себе і не дасть себе ображати, саме тому в умовах конфлікту їй не загрожує формування певних суїцидальних тенденцій. Проте вона може виступати достатньо конформною з метою отримання підтримки себе або своїх уподобань, що часто можуть виступати і уподобаннями мікросоціального оточення чи референтної групи. Може видатися залежною щодо того, яким чином себе поводить, але це може бути, навпаки, лише свідченням іiі м'якості та довірливості щодо свого оточення. Саме тому що інші можуть не очікувати на таку поведінку, iii можуть неправильно розцінити. Але загалом така особистість $€$ достатньо адаптованою щодо конфліктів у мікросоціальному середовищі та загалом, адже здатна адекватно змінювати свою поведінку відповідно до оточення, в якому вона знаходиться.

\section{ВИСНОВКИ}

Емпірично та теоретично було визначено, що антивітальні переживання представляють собою найбільш ранній етап суїцидальної динаміки та передують формуванню суїцидальних ідеацій. Вони характеризуються поступовим посиленням прихованих i малоусвідомлених авітальних тенденцій, які ослаблюють прагнення підтримувати життя. Класичний теоретичний концепт може і має бути певною мірою розширений за рахунок додаткового дослідження антивітальних переживань як внутрішньої форми активності пресуїцидального етапу, що 3 супутніми факторами суїцидального ризику впливають на подальший розвиток або припинення формування суїцидальної поведінки.

Фактори ризику (суїцидогенні фактори) - це будь-які причини, умови або впливи, що викликають як етіопатогенетичний компонент формування суїцидальної поведінки. До них можна віднести: демографічні, психопатологічні, психологічні, біологічні, психічні травми та інші фактори. Антисуїцидальними факторами своєю чергою $\epsilon$, наприклад: соціальна підтримка, адаптивні механізми долаючої поведінки, моральне неприйняття самогубства і таке інше. 
Складність операціоналізації предмету дослідження, а саме такого поняття, як антивітальні переживання, полягає у тому, що це внутрішня форма поведінки, що утворює собою пресуїцидальний етап і проявляє себе у певних фантазіях щодо безглуздості, «непотрібності» життя, без чітких уявлень про власну смерть, що властиві подальшим етапам суїцидальної активності. Фактично не існує оптимального адекватного зовнішнього поведінкового вираження певних проявів антивітальних переживань (оскільки вони не володіють конкретною аутоагрессивною (суїцидальною) спрямованістю) чітко описаних у літературі, на основі яких можна було б свідчити про певний ступінь розвитку переживань в актуальній картині свідомості для індивіда. Але, безумовно, вони являють собою один із чинників розвитку суїцидальної поведінки загалом.

Щодо прямих результатів емпіричного дослідження було підтверджено, що антивітальні переживання проявляють себе у внутрішній формі активності пресуїцидального етапу і з супутніми факторами суїцидального ризику впливають на подальший розвиток або припинення формування суїцидальної поведінки, що в основному розвивається в умовах мікросоціального конфлікту. Саме цим і можна пояснити наявність певних закономірностей у розвитку суїцидальної поведінки.

Власні теоретичні розробки в рамках дослідження антивітальних переживань було підтверджено також за рахунок проведення факторного аналізу, що дозволив виявити 11 інтегральних факторів реагування особистості відповідно до прояву антивітальних переживань та ідеацій в умовах конфлікту i змістовно проінтерпретувати їх. Було виділено наступні фактори: Соціальна егоїстичність, Соціальна конформність, Мінлива егоїстичність, Розважлива егоїстичність, Соціальна залежність, Соціальна ригідність, Захисна егоїстичність, Соціальна налаштованість, Егоїстична відстороненість, Егоїстична поміркованість та Впевнена егоїстичність.

У підсумку можна зазначити, що продовження запропонованого теоретичного розгляду феномену може бути проведене в подальших дослідженнях, зокрема як і робота з виділеними факторами.

\section{АНОТАЦІЯ}

Для комплексного вивчення такого феномену, як формування антивітальних переживань, які можуть трансформуватися в суїцидальні ідеації та впливати на суїцидальний ризик, варто поєднувати індивідуально-психологічний, сціально-психологічний та загальнопсихологічний контексти вивчення особистості. 
Антивітальні переживання представляють собою найбільш ранній етап суїцидальної динаміки. Вони характеризуються поступовим посиленням прихованих і малоусвідомлених авітальних тенденцій, які ослаблюють прагнення підтримувати життя. Відповідно до цього 3 метою розв'язання питань у цьому дослідженні було визнано доцільним застосування системного підходу, 3 урахуванням таких особливостей психічної реальності та активності людини, як ставлення до майбутнього, у формі ядра мотивації, смисложиттєвих орієнтацій, загальної адаптованості особистості, форм та стратегій поведінки щодо подолання конфліктів та життєвих негараздів загалом, взаємодії 3 соціальним оточенням та розуміння i приймання кінцевої форми існування.

3 огляду на вищезазначені особливості дослідження було використано такі методики: 1) Опитувальник суїцидального ризику (ОСР) О.Г. Шмельова; 2) П'ятифакторний особистісний опитувальник; 3) Методика «Ціннісні орієнтації» Рокіча; 4) Опитувальник «Способи долаючої поведінки» Лазаруса; 5) Методика діагностики міжособистісних відносин Лірі.

Емпірично та теоретично було визначено, що антивітальні переживання представляють собою найбільш ранній етап суїцидальної динаміки та передують формуванню суїцидальних ідеацій. Власні теоретичні розробки в рамках дослідження антивітальних переживань було підтверджено також шляхом проведення факторного аналізу, що дозволив виявити 11 інтегральних факторів реагування особистості відповідно до прояву антивітальних переживань та ідеацій в умовах конфлікту і змістовно проінтерпретувати їх.

\section{ЛІТЕРАТУРА}

1. Билле-Браге У., Чуприков А.П., Пилягина Г.Я., Войцех В.Ф., Крыжановская Л.А., Жабокрицкий С.В., Сонник Г.Т. Глоссарий суицидологических терминов. Методическое пособие. URL: http://www.psychiatry.ru/lib/56/book/110 (дата звернення: 20.04.2020).

2. Дзюб Г.К., Кузнецов В.М., Нестерчук Н.В. Ургентна психіатрія (клініка, психодіагностика, терапія невідкладних станів). Київ, 2010. $190 \mathrm{c}$.

3. Зотов П.Б., Уманский С.М. Клинические формы и динамика суицидального поведения. Суицидология, 2011. № 1. С. 3-7.

4. Клінічна психологія: словник-довідник / авт.-уклад. С.В. Діденко. Київ : Академвидав. Серія «Nota bene», 2012. 320 с.

5. Кузнецов В.Е. Комплексные исследования в суицидологии. Москва, 1986. 485 с. 
6. Шевчук О.С. Особливості підходу до психодіагностики антивітальних переживань. Проблеми особистості в сучасній науці: результати та перспективи дослідження, 17 березня 2017 р. : Матеріали XIX Міжнародної конференції молодих науковців / за ред. I.В. Данилюка, С.Ю. Пащенко. Київ : Логос, 2017. С. 336-339.

\section{Information about the author: Shevchuk O. S.,} $\mathrm{PhD}$ Student at the Department of Psychodiagnostics and Clinical Psychology, Psychologist at the Psychological Service of the Faculty of Psychology Taras Shevchenko National University of Kyiv 2A, Prospekt Hlushkov, Kyiv, 03680, Ukraine 